\title{
Assessment of the Competitiveness of Kazakhstan's Exports
}

\author{
Amirbekova Ainur \\ Dept. of Economics, L.N. Gumilyov Eurasian National University, 2 Satpaev Street \\ Astana, Kazakhstan, 010000; E-mail: amirbekova_as@enu.kz \\ Madiyarova Diana \\ Dept. of Economics, L.N. Gumilyov Eurasian National University, 2 Satpaev Street \\ Astana, Kazakhstan, 010000 ; E-mail: madiyarova_dm@enu.kz
}

\section{Doi:10.5901/mjss.2015.v6n6p443}

\begin{abstract}
This article analyses the competitive advantages of Kazakhstan to trade with other countries, as well as commodity structure in the global market. The paper presents an empirical analysis of the identified competitive advantages of Kazakhstan export products and proposes Lafay index for Kazakh six-digit product category level. The analysis reveals that although Kazakhstan shows a revealed comparative advantage in a number of sectors, but the product groups with strong comparative advantage show a significant variation.
\end{abstract}

Keywords: Export competitiveness; competitive advantage; Lafay Index

\section{Introduction}

One of the components of country's economy competitiveness as a whole is the competitiveness of domestic products at the regional or global market in particular. In this regard, the development and diversification of the export potential of the country becomes an important issue. Therefore, the important task is the specialization of the country in the most efficient and competitive segments of the economy. In this regard, the role of quantitative assessment of potential competitive advantages is becoming important, that allows determining the extent to which certain factors influence on the formation of export capacity in the country.

The aim of the study is to determine the competitive advantages of Kazakhstan to trade with other countries on the basis of revealed comparative advantages, as well as commodity structure. This study will assess the export competitiveness of Kazakhstan in product level with Lafay index, calculations for 4170 Kazakhstan commodity positions by six-digit commodity nomenclature of foreign trade activities (CNoFTA). The study period covers the time span from 2001 to 2012, export of which was carried out during the considered time interval, which allows identifying clear trends in changing activities. Based on index calculation, it can be determined whether the whole country has "revealed" comparative advantage.

The practical significance of the study lies in the fact that its main findings and conclusions arising from it can be used in assessing the export competitiveness of Kazakhstan for WTO accession and will improve the competitiveness of goods and services in the global market.

\section{Theoretical Framework}

The main theoretical and methodological aspects of export issues have been thoroughly analyzed in the studies of both domestic (Khusainov, 2010; Madiyarova, 2005; Temirgaliev, 2003) and foreign authors (Bernard et al., 2007; Farole et al., 2007; Fetscherin et al., 2010; Tochinskaya and Aksen, 2014; Lall, 2005; Bruneckiene and Paltanaviciene, 2012; Kumar, 2010; Tavares and Young, 2002). Export competitiveness was measured through an analysis of the factors and conditions (Farole et al., 2010; Bruneckiene and Paltanaviciene, 2012; Gigov, 2013; Alem, 2013; Feghali et al., 2007), by creating a combined indices that facilitate international trade (Saboniene, 2011; Wignaraja et al., 2004; Kumar, 2010), or separate indices (Bruneckiene and Paltanaviciene, 2012; Bojnec and Ferto, 2014; Mahmood, 2001).

However, there are differences in experts' approach, not only on factors determining the export competitiveness, but also on methodological aspects of measuring the competitiveness level. Each method has its advantages and 
disadvantages. Scientists are now trying to find the most reliable, methodologically justified method that could be used in strategic planning, enhancing the competitiveness of domestic exports and gross national economy. For example, Bruneckiene et al. (2012) believe that the use of the index is the best way to measure the export competitiveness. Malakauskaite (2010) and Mikulis et al. (2011) focus on the development of a model to measure the export competitiveness through factors and their specific targets.

The main research application of Saboniene (2009) has been analysis of the country export specialization. Wignaraja et al. (2004) focused only on three indicators constituting the index to be applied that impedes the establishment of the cause-effect relationship between factors effecting export competitiveness. Bojnec et al. (2014) analysed the export competitiveness of dairy products of the European Union countries on global markets, using the revealed comparative advantage index. Mahmood (2001) analysed Malaysia's export competitiveness by SITC three-digit product category level with the help of Balassa Index.

\section{Methodology and Data}

In case when evaluation of the competitiveness in the world market of a particular product or a total export of the country then the macroeconomic approach is used. In this case, a detailed parametric mapping is not possible, which is used in the methods of the microeconomic approach, since the amount of data being analysed is too large and the test results may not be accurate. In this regard, in the methods of macroeconomic approach are used indicators such as exports and imports of the country, the world's exports and imports, production and consumption of goods in the country and price levels..

The method of determining the competitiveness of the product involves the calculation of the Lafay index (LFI), which eliminates the influence of market factors and inflation and takes into account the imports of the country, especially if it is large.

$$
L F I=100^{*}\left(\frac{X i j-M i j}{X i j+M i j}-\frac{\sum_{j=1}^{N}(X i j-M i j)}{\sum_{j=1}^{N}(X i j+M i j)}\right) *\left(\frac{X i j+M i j}{\sum_{j=1}^{N}(X i j-M i j)}\right),
$$

Where

$N$ - a number of different kinds of goods.

The positive values of Lafay index is to indicate the existence of competitive advantages. The larger the coefficient, the higher the level of competitiveness. On the contrary, negative values indicate a lack of competitiveness of products. Other important index properties are restrictions on minimum and maximum value: -50 (full despecialization) to +50 (full competitiveness).

The level of competitiveness of Kazakh products was calculated by using statistical information platform "Trade Map", developed by the International Trade Centre (International Trade Centre UNCTAD / WTO, ITC) and designed for the collection and display of data on trade statistics in the world. As a source of statistics on foreign trade of Kazakhstan, Trade Map uses data provided by the Agency of Statistics of Kazakhstan, and the data from the UN COMTRADE. There is slight difference between data of the Statistics Agency of Kazakhstan and Trade Map on key indicators of foreign trade.

\section{Empirical Results}

In accordance with the chosen methodology for determining the level of competitiveness of Kazakh products in the world market, Lafay index were calculated for the 4170 Kazakhstan headings on six-digit HS code, exported in the period from 2001 to 2012. For the formation of holistic and objective views, indices were calculated even for those headings, the export of which was carried out only for one year from the entire considered time interval. In calculating the Lafay index, those headings, for which exports are equal to 0 , were excluded from the analysis, even if import volumes of the headings are significant, because this index for these headings will be negative, which will increase the share of noncompetitive goods in the total exports and distort the real situation.

The results of analysis display a greater variation to particular product groups. They are stable for the product groups with comparative disadvantage, but the product groups with strong comparative advantage show a significant variation. (Table A.1). 
Table A.1 Results of Lafay Index calculation for the exports of Kazakhstan for the period 2001-2012

\begin{tabular}{|l|c|c|c|c|c|c|c|c|c|c|c|c|}
\hline & 2001 & 2002 & 2003 & 2004 & 2005 & 2006 & 2007 & 2008 & 2009 & 2010 & 2011 & 2012 \\
\hline Total exported commodities positions of RK & 1949 & 1836 & 1903 & 2017 & 2040 & 2045 & 2002 & 2132 & 2235 & 2052 & 2439 & 2443 \\
\hline of which: & & & & & & & & & & & & \\
\hline the number of positions for which the Lafay index> 1 & 389 & 350 & 347 & 361 & 320 & 335 & 323 & 310 & 287 & 258 & 275 & 284 \\
\hline share in total exports (\%) & 19,96 & 19,06 & 18,23 & 17,90 & 15,69 & 16,38 & 16,13 & 14,54 & 12,84 & 12,57 & 11,28 & 11,63 \\
\hline the number of positions for which the Lafay index <0 & 813 & 743 & 808 & 983 & 1052 & 1075 & 1077 & 1202 & 1252 & 1137 & 1509 & 1619 \\
\hline share in total exports (\%) & 41,71 & 40,47 & 42,46 & 48,74 & 51,57 & 52,57 & 53,80 & 56,38 & 56,02 & 55,41 & 61,87 & 66,27 \\
\hline Number of commodities positions, export and import of which is 0 & 747 & 743 & 748 & 673 & 668 & 635 & 602 & 620 & 696 & 657 & 655 & 540 \\
\hline
\end{tabular}

Source: Calculated by the author based on data from Trade Map

Curve in the figure, showing the number of competitive products, graphically repeats the curve that shows the total number of exported goods of Kazakhstan, which confirms the earlier conclusion about the lack of competitiveness of Kazakhstan's new products, which are exported outside the country.

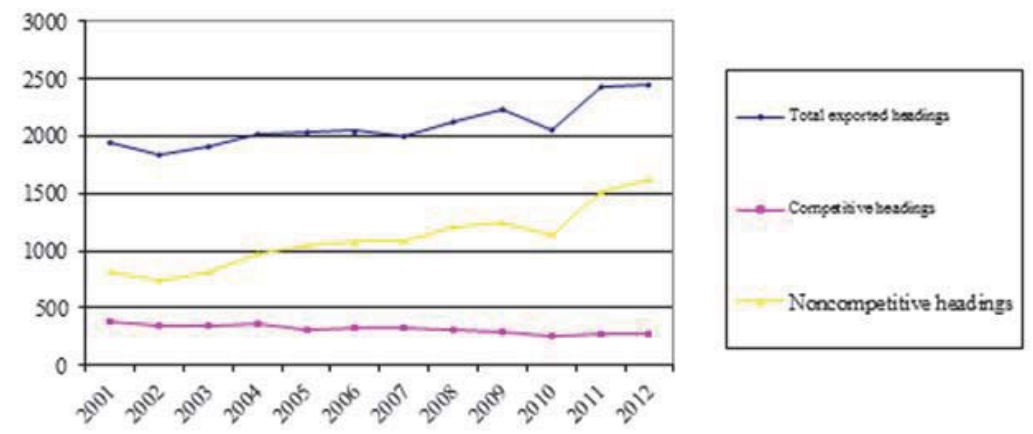

Figure A.1 The level of competitiveness of Kazakhstan exports during the period 2001-2012 according to the Lafay index

Depending on the received values of Lafay index, the entire Kazakh exported goods can be divided into the following categories.

The first category covers uncompetitive headings throughout the period under study (LFI $<0$ from 2001 to 2012). This category includes 1,692 commodity items for which the Lafay index values were stably less than 1.

The second category includes competitive headings throughout the period under study (LFI> 0 from 2001 to 2012), the amount of which is equal to 104. In addition, 59 headings, the level of competitiveness of which has remained consistently high since 2001 according to Lafay index. These headings are "calcined pyrite", "copper ores and concentrates", "zinc ores and concentrates", "chrome ores and concentrates", "antimony ores and concentrates", etc. The coincidence of the results suggests that we can conclude the real competitiveness of these products of Kazakhstan in the world market.

The third category includes headings with increasing levels of competitiveness ( $L F I<0$, then $L F I>0)$. This item includes 85 headings.

The fourth category includes headings with declining levels of competitiveness ( $L F I>0$, then $L F I<0)$. This group consists of 95 headings such as "Meat of bovine animals, frozen: Carcasses and half-carcasses", "onions and shallots", "watermelon", "asbestos", "calcined petroleum coke," etc. Twenty products from this category also belong to the category of goods with declining levels of competitiveness according to RCA, two headings to the category with first increased, then the reduced level of competitiveness.

The fifth category includes headings, the level of competitiveness of which first increased, then decreased. The number of headings in this group is 78. Here are headings such as "other vegetables, fresh or chilled", "wheat gluten, whether or not dried", "flour, groats and meal from soybeans," "beet sugar" "tarred macadam", "nickel ores and concentrates", "gas oil and other gaseous hydrocarbons", "vanadium oxides and hydroxides", "copper-based alloys and zinc (brass)," etc. 
Thus, the results of the calculation of Lafay index confirm previous findings about the low level of competitiveness of the Kazakh exports as a whole, despite the presence of headings that are competitive in the period under study. The matching of the distribution of headings in categories according to the received value of the index suggests the correctness of calculations, and can serve as a basis for further development of proposals to improve the competitiveness of the domestic exports. As noted earlier, according to the calculations of Lafay index the category of competitive commodity items during considered period includes 104 commodity items. The share of this category in the value of exports of the Republic of Kazakhstan decreased from 91.96\% in 2011 to 88.19\% in 2012. Maximum weight belonged to commodity items data was 92.41\% in 2010, the minimum was observed in 2012.

\section{Concluding Remarks}

By summarizing the results of calculations, we arrive at the following conclusions.

During the under study period Kazakhstan strengthened revealed comparative advantage in the category of raw commodities by increasing exports of raw materials.

The share of competitive products in the total exports of the country is very small and there is a tendency to reduce it at the beginning of the under study period. The number of exported commodity increases, therefore, this growth provides uncompetitive products.

Fitting index calculation results show that the products are competitive in those industries in which Kazakhstan has traditionally formed a comparative advantage. At the same time, there was a weakening competitive position of Kazakhstan in the category of food industry and agriculture. Nevertheless, low added value commodities that are consistently slightly competitive. However, at the current situation by this commodity nomenclature, it is very difficult for Kazakhstan to compete in the domestic market and especially on the international market. The absence of comprehensive structural reforms aimed at the development of the processing sector in different sectors will lead to increasing raw material exports.

On the basis of these results, we can recommend that the Kazakh producers should place themselves into already existing international value chain, specializing in the production of knowledge, knowledge-intensive, high-tech products. Thus it is necessary to develop the processes of production, which may involve advantage skills of the Kazakh workforce in R \& D. Kazakhstan has advantages in the category of low-tech and capital goods, so it is advisable to place the final production of this category in the country and to build international chain.

Keeping of the level of competitiveness high is, undoubtedly, a positive aspect, as to hold a position in the world market of goods is difficult. However, the presence of a large number of commodities with a declining level of competitiveness may lead to worsening the situation when we enter the WTO.

\section{References}

Bernard, A. and Jensen J. (1990). Exceptional Exporter Performance: Cause, Effect, or Both? Journal of International Economics, 47, 1, $1-25$.

Bojnec, S. and FERTO, I. (2014). Export competitiveness of dairy products on global markets: The case of the European Union countries. Journal of Dairy Science, 97, 10, 6151-6163.

Bernard et al. (2007). Spatial knowledge diffusion through collaborative networks. Regional Science, 86, 3, 341-350.

Feghali, T. et al. (2007). Determinants of Lebanon's ICT Export Competitiveness: Evaluating a Country's Readiness to Export ICT. Journal of Transnational Management, 12, 3, 37-41.

Gigov, I. (2013). Macedonian Export Competitiveness and its Improvement. Economic Development, 3, 185-200.

Bruneckiene, J. and PALTANAVICIENE, D. (2012). Measurement of Export Competitiveness of the Baltic States by Composite Index. English Economics, 23, 1, 50-62.

Mikulis, J. and RUZEVICIUS, J. (2011). Management systems and competitiveness of a country-Lithuanian context. Current Issues in Business Law, 3, 0, 26-46.

Khusainov, B. (2011). Country Preferences and Belarus, Kazakhstan and Russia Export Competitiveness. Eurasian Economic Integration, 2, 11, 71-96.

Kumar, A. (2010). Exports of Livestock Products from India: Performance, Competitiveness and Determinants. Agricultural Economics Research Review, 23, 57-67.

Mahmood, A. (2001). Sifting Export Specialization and the Competitiveness of the Malaysian Manufacturing: Trends and Analysis. The International Trade Journal, 15, 2, 187-219.

Lall, S. (2005). FDI, AGOA and Manufactured Exports by a Landlocked, Least Developed African Economy: Lesotho. Journal of Development Studies, 41, 6, 998-1022, 2005.

Sabonien, "The Transformation of Lithuanian Economy: Dimension of Manufacturing," Econ. Manag., vol. 16, pp. 295-302, 2011. 
Farole, T. et al. (2010). Analyzing trade competitiveness: a diagnostics approach. Policy Research Working Paper.

Fetscherin, I. and JOHNSON, J. (2010). Assessing the export competitiveness of Chinese industries. Asian Business Management, 9 , $3,401-424$.

Мадиярова Д. (2005). Мировые товарные рынки. Алматы: Изд-во «Экономика», 420 стр.

Темиргалиев, Б. (2003). Основы внешнеэкономической деятельности Республики Казахстан. (Издание 2-е, переработанное и дополненное) - Алматы, -350 стр. 